\title{
PENGAJARAN KOSA KATA BAGI MAHASISWA EFL DENGAN MENGGUNAKAN GAME
}

\author{
Gaguk Rudianto $^{(1)}$ dan Yessie Aldriani ${ }^{(2)}$ \\ ${ }^{(1)}$ Sastra Inggris, Universitas Putera Batam, gagukrudianto@gmail.com \\ ${ }^{(2)}$ Sastra Inggris, Universita Putera Batam, aldrianiyessie@gmail.com
}

\begin{abstract}
Regardless of the vocabulary teaching in EFL students is neglected, the role of vocabulary becomes more and more essential in both second language teaching more over foreign language one. Putting off vocabulary teaching happens because many English teachers are not confident enough to decide both method and technique of teaching vocabulary. This paper is written to give interesting alternative of vocabulary teaching technique with the hope to meet challenge of teaching vocabulary

Keyword: Vocabulary, teaching technique
\end{abstract}

\section{Latar Belakang}

Berbicara, membaca, menulis dan mendengarkan adalah unsur-unsur Bahasa yang sangat penting dalam menguasai suatu Bahasa. Hal ini berarti apabila seseorang ingin menguasai suatu bahasa terutama bahasa asing maka ia harus menguasai unsur-unsur bahasa tersebut. Walaupun demikian keempat unsur Bahasa tersebut tiraklah bararti apa-apa apabila ia tidak menguasai kosa kata atau vocabulary. Tanpa menguasai kosakata seseorang tidak akan bisa berbicara apapun, tidak akan bisa mengerti apa yang dia baca, tidak akan dapat menulis dan juga tidak akan dapat mengerti apa yang dia dengar. Penguasaan kosa kata adalah sesuatu hal yang sangat fital dalam penguasaan Bahasa asing termasuk Bahasa Inggris.

Dalam usaha penguasaan Bahasa Inggris, keempat unsur bahasa tersebut harus dipelajari semua tanpa memisahkan satu dengan yang lainnya. Dengan kata lain keempat unsur Bahasa tersebut harus dipelajari sebagai suatu kesatuan.
Cara yang paling tepat dan efektif dalam usaha mempelajari bahasa Inggris yaitu mengembalikan fungsi bahasa tersebut sebagai alat komunikasi. Karena bahasa sebagai suatu alat komunikasi maka satu-satunya cara yang paling tepat untuk mempelajari bahasa adalah menggunkannya dalam berkomunikasi baik berkomunikasi secara lisan maupun tulisan dalam situasi formal maupun informal.

Pembelajaran kosakata adalah salah satu faktor paling penting yang dialami pelajar bahasa asing selama proses belajar bahasa asing. Pembelajaran kosakata dulu merupakan aspek pembelajaran bahasa yang terabaikan. Namun, dalam beberapa tahun terakhir, ketertarikan pada bidang ini telah tumbuh sangat besar. Guru bahasa telah tertarik dalam mencari pendekatan yang efektif untuk meningkatkan pembelajaran kosakata. Pembelajaran kosakata lebih penting daripada keakraban dengan bentuk dan makna dari sebuah kata (Ahmadi Mohammad Reza, 2012). 
Penguasaan kosakata sering dipandang sebagai alat penting untuk pelajar bahasa asing karena kosakata yang terbatas dalam bahasa asing akan menghambat keberhasilan komunikasi yang dilakukan (Schmitt N., 2000) seperti dikutip oleh (Alqahtami, 2015). Beliau menekankan bahwa "pengetahuan leksikal merupakan pusat kompetensi komunikatif yang diperlukan untuk dapat berakuisisi dalam bahasa kedua. Dari kutipan di atas menyatakan penguasaan kosakata akan mempengaruhi keberhasilan komunikasi. Komunikasi dalam bahasa asing akan gagal jika mereka tidak memiliki kosakata yang cukup untuk mengekspresikan ide dan gagasan mereka.

Secara umum, kurangnya kemampuan untuk menggunakan strategi dalam pembelajaran kosakata telah mempengaruhi keberhasilan siswa dalam pembelajaran bahasa asing (Laufer B, 2003). Pengetahuan kosakata dalam pembelajaran bahasa asing memiliki efek kemampuan membaca dan menulis pada siswa EFL (Alderson, 2000). Beberapa penelitian yang telah dilakukan menunjukkan adanya hubungan yang signifikan antara pembelajaran kosakata dan pembelajaran bahasa asing (Qian, 2002).

\section{Tinjauan Pustaka}

Fungsi dan peran kosakata sangatlah fital dalam pembelajaran Bahasa Inggris baik sebagai Bahasa kedua maupun sebagai Bahasa asing. Walaupun peran kosakata yang begitu signifikan, pengajaran kosakata seringkali terabaikan dibandingkan dengan unsur Bahasa yang lainnya. Kosakata sering kali tidak diajarkan secara berkesinambungan. Kosakata sering hanya disisipkan saja ke dalam pengajaran unsur Bahasa lainnya seperti sering kali kosakata disisipkan dalam pongajaran reading, speaking maupun lainnya.

Pengajaran Kosakata

Penelitian terbaru menunjukkan bahwa pengajaran kosakata mungkin bermasalah karena banyak guru tidak yakin tentang praktik terbaik dalam pengajaran kosakata dan kadangkadang para guru tidak mengetahui bagian mana penekanan instruksional pembelajaran harus diberikan. (Thorburry S., 2002). Para guru setuju bahwa hampir tidak mungkin untuk belajar bahasa tanpa menguasai kata-kata; bahkan komunikasi antar manusia didasarkan pada katakata. Demikian juga para siswa setuju bahwa akuisisi kosakata merupakan faktor utama dalam mengajar bahasa (Walter \& J, 2004). Mengajarkan kosakata adalah salah satu bagian pengajaran bahasa Inggris yang paling banyak dibicarakan sebagai bahasa asing. Ketika proses belajar mengajar berlangsung, masalah akan muncul pada guru. Mereka memiliki masalah tentang cara mengajar siswa untuk mendapatkan hasil yang memuaskan. Guru harus mempersiapkan dan menemukan teknik yang tepat, yang akan diimplementasikan kepada siswa. Seorang guru yang baik harus mempersiapkan dirinya sendiri dengan berbagai teknik dan mutakhir. Guru harus mampu menguasai materi mereka agar dipahami oleh 
siswa, dan membuat mereka tertarik dan bahagia dalam proses belajar mengajar di kelas.

Para guru harus benar-benar peduli bahwa mengajarkan kosa kata akan sangat berbeda baik pengajaran kosakata dalam Bahasa Inggris sebagai Bahasa kedua akan sangat jauh berbeda dengan pengajaran kosakata Bahasa Inggris sebagai Bahasa asing. Demikian juga dengan peserta didik atau siswanya. Pengajaran kosakata bagi anak-anak akan sangat berbeda dengan pengajaran kosakata bagi orang dewasa. Jadi para guru perlu mempersiapkan teknik yang baik dan jitu yang disesuaikan dengan materi yang akan diajarkan untuk mendapatkan target pengajaran bahasa.

Menurut beberapa ahli kosa kata dibagi menjadi dua bagian yaitu receptive dan productive vocabulary. Receptive vocabulary adalah kemampuan untuk memahami suatu kata dengan cara mendengarkannya atau melihatnya misalnya seseorang mampu mengerti orang lain berbicara Bahasa Inggris dengan baik dan benar tanpa mampu memberikan respon atau jawaban atas perkataan tersebut, kemampuan penguasaan kosa orang tersebut tergolong receptive vocabulary, sedangkan apabila orang tersebut disamping mengerti isi pembicaraan dalam Bahasa Inggris orang lain dia juga mampu memberikan respon atau jawaban dari apa yang dia dingarkan maka kemampuan kosa katanya tergolong productive vocabulary. Dengan kata kemempuan productive vocabulary adalah kemempuan untuk dapat menghasilkan kata-kata ketika seseorang berbicara atau menulis dengan baik dan benar. Pada umumnya penguasaan kosa kata akan diperkenalkan secara receptive atau dengan cara didengarkan terlebih dahulu seperti ketika kita mengajarkan kosa kata pada anak kita. Kita lakukan dengan cara mengatakan kata tersebut kepadanya. Setelah anak tersebut mengerti kemudian dia akan mencoba manggunakan kata tersebut dengan cara mengulang apa yang sudah didengarkan atau dengan cara productive. Karena proses penguasaan kosa kata dimulai dari mendengarkan (receptive) kemudian setelah mengerti makna kata yang sudah diterima tersebut akan digunakan baik dalam bentuk Bahasa lisan maupun Bahasa tulisan maka proses penguasaan kosa kata harus dianggap sebagai sesuatu yang kontinum atau berkelanjutan dimana pengusaan kosa kata tumbuh dari proses tersebut.

\section{Pegajaran Kosakata Melalui "Wheel of Fortune Game"}

Ada banyak tehnik pengajaran kokakata yang efektif. Salah satu tehnik tersebut adalah menggunakan game yang mirip dengan "Wheel of Fortune" yang modifikasi sedemikian rupa sehingga dapat dipakai sebagai sarana pembelajaran kosakata yang mengasikkan. Wheel of Fortune adalah sebuah acara permainan Amerika Serikat yang diciptakan oleh Merv Griffin. Nama program ini berasal dari sebuah roda besar yang teah didisign secara khusus guna menentukan menentukan jumlah uang dan hadiah yang dapat dimenangkan oleh para peserta dalam acara 
tersebit.

Acara permainan ini disiarkan pertama pada tahun 1975 di jaringan televisi seharian. Versi saat ini adalah hasil sindikat prime time yang di akses sejak 19 September 1983. Musim ke30 dimulai pada tanggal 17 September 2012. Ini adalah rencana permainan sindikat sepanjang sejarah televisi Amerika dan terpanjang kedua baik dalam jaringan atau sindikasi (di belakang The Price is Right).

Nama Permainan : Guessing Word

Tujuan : Menebak kata yang ada di tangan guru pembimbing.

Jumlah pemain : 2 sampai 14 orang. Jumlah pemain diatas 2 orang akan dibagi menjadi 2 grup dengan kemampuan Bahasa Inggris yang berfariasi.

Scoring : Setiap kosonan yang berhasil ditebak akan mendapat nilai 10, sedangkan untuk vocal akan dilakukan pembelian dengan cara pengurangan score yang didapat setiap sesi permainan.

Peralatan : Spidol, kertas, papan tulis, penghapus.

Persiapan : Guru pembimbing akan menulis suatu kata, phrase, klausa atau kata-kata mutiara dalam Bahasa Inggris di selembar kertas sebagai control atau kunci jawaban, kemudian dari kata tersebut guru akan menentukan katagori dari kata tersebut.
Misalnya guru pembimbing menuliskan kata " Time is Money". Maka di papan tulis beliau akan menuliskan katagori "Wise Word". Setelah itu guru pembimbing akan menghitung jumlah huruf yang ada pada mystery word tersebut kemudian membuat garis-garis yang akan diisikan dengan huruf yang sesuai dengan mystery word. Setiap garis hanya boleh diisi dengan satu huruf saja. Misalnya dari kata "Time is Money" maka guru pembimbing akan membuat garis seperti berikut:

Category: Wise Word

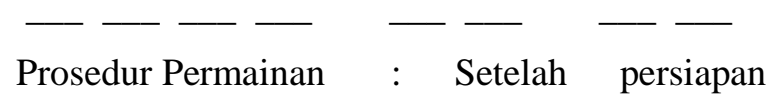
dilakukan, guru pembimbing akan menentukan giliran kelompok yang pertama untuk menebak konsonan yang ada pada katagori tersebut dengan cara menyebutkan konsonannya dan diikuti oleh kata pendukung misalnya. I ask "T" for "Tea". "M" for "mother" dan lainnya. Apabila tebakan dari anggota group tersebut benar maka guru pembimbinh akan menuliskan abjat tersebut di posisi yang tepat sama persis dengan 
mystery word yang ada di kertas yang dia pegang. Kemudian konsonan yang tepat tersebut dihitung dan dikalikan dengan 10. Misalnya dalam mystery word "Time is Money" apabila ada seorang peserta minta consonan "M", karena terdapat dua huruf "M" maka nilai yang didapatkan pemain yang meminta konsonan tersebut adalah 20 dan seterusnya. Giliran meminta huruf hanya diberikan kepada anggota grup yang bisa menebak konsonan yang betul saja. Giliring meminta huruf atau menebak mystery word akan diberikan kepada lawan main apabila grup tersebut gagal meminta konsonan yang benar yang sesuai dengan mystery word.

Cara Menebak :Suatu grup yang berhasil menebak beberapa konsonan dengan benar yang ditandai dengan konsonan tersebut ditulis di tempat yang telah disediakan maka grup tersebut (yang sedang memiliki giliran) bisa menebak langsung dengan cara mengatakan mystery word melalui garis-garis yang ada di papan. Namun apabila grup (yang sedang memiliki giliran) tersebut tidak yakin dengan jawaban yang akan mereka katakan maka mereka bisa nembeli vocal (apabila mereka mempunyai nilai yang didapat dari jawaban tebakan konsonan sebelumnya) dengan cara mengatakan "I buy vowel "a" for "apple". Vocal akan dihargai 10 untuk satu jenisnya bukan jumlahnya. Misalnya dalam mystery word "Time is Money" terdapat 2 vokal "e" maka kedua untuk nilai vocal tersebut akan dipotongkan dari grup yang membeli. Nilai yang dipotong adalah 10. Ingat pembelian hanya bisa dilakukan oleh grup yang sedang memiliki giliran dan mempunyai nilai. Nilai hanya diberikan kepada grup yang berhasil menebak mystery word dengan benar. Adapun parhitungan nilai adalah nilai setiap permainan dikurangi dengan pembelian vocal ditambah 100 untuk jawaban mystery word yang benar. Untuk menebak mystery word dapat dilakukan pada saat permainan sedang berlangsung. Hal ini dapat dilakukan apabila peserta sudah merasa yakin akan jawaban dari mystery word 
tersebut. Namun adakalanya suatu grup belum mendapatkan petunjuk untuk menjawab mystery word hingga waktu yang telah disepakati habis. Apabila hal ini terjadi grup tersebut harus mendiskusikan dengan anggotanya untuk memberikan jawaban profesi mystery guess beserta alasannya. Pada saat anggota grup menebak profesi dari mystery guess, mystery guess dilarang menjawabnya secara langsung tetapi guru pembimbing akan memandu jawabannya dengan menanyakan kata petunjuk yang akan mengarahkan ke jawaban profesi mystery guest.

Ungkapan yang sering digunakan:

1. I ask a " $\mathrm{T}$ " for "tear".

2. I ask a "B" for "bear".

3. I ask a " $D$ ' for "deer".

4. I ask a "W" for "window"

5. I buy a vowel "I" for "ice cream".

6. I guess it is a wise word "Better late than never".

Pengajaran Kosakata Melalui "Kuis Siapa Dia"

Siapa Dia (disingkat SD) adalah salah satu acara kuis Indonesia ciptaan Ani Sumadi. Acara ini ditayangkan di TVRI pada tahun 1992-
1998 dengan pembawa acara Aom Kusman. Setelah 15 tahun tidak tayang, acara ini kembali ditayangkan di TVRI sejak bulan Maret 2013 sampai Agustus 2013 dengan pembawa acara Denny Chandra dan sekarang pindah ke Trans 7 dengan pembawa acara Ananda Omesh. Kuis seperti ini pertama diperkenalkan dengan nama what's my line yang disiarkan di Amerika Serikat pertama pada era 1950-an hingga 1970-an. Dan setelah itu, beberapa negara mulai mengadopsi kuis-kuis serupa di televisi-televisi negara tersebut termasuk Indonesia.

Kuis ini dibagi menjadi tiga sesi yaitu tebak profesi yang terdiri dari dua sesi. Pertama dengan cara menghadirkan satu mystery guest. Disini para panelis yang terdiri dari empat orang akan bertanya selama 10 menit dengan menggunakan pertanyaan yes, no questions questions. Sedangkan mystery guest hanya boleh menjawab "ya", "tidak" atau "bisa ya bisa tidak". Setelah 10 berakhir, para panelis harus menyimpulkan profesi dari mystery guest tersebut. Sedangkan pada sesi tebak profesi sesi kedua akan dihadirkan tiga orang mystery guest. Dimana diatara ketiga orang tersesut hanya terdapat satu orang yang benar-benar menduduki profesi yang tertentu. Tugas panelis disini mencari orang yang benarbenar menduduki profesi tersebut dengan cara meminta masing-masing mystery gust untuk memperagakan gerakan-gerakan tertentu yang dapat dijadikan petunjuk untuk menentukan mystery guest yang benar-benar berprofesi 
tersebut. Aturan disini panelis tidak boleh mengajukan pertanyaan kepada mystery guest. Para panelis hanya dapat meminta memperagaakan gerakan tertentu yang berhubungan dengan profesi yang dikuiskan. Sedangkan pada sesi ketiga adalah tebak gambar. Gambar tersebut adalah gambar tokoh terkenal yang harus ditebak oleh panelis melalui potongan-potongan gambar yang disediakan. Untuk sesi dua dan tiga dalam kuis siapa dia ini tidak digunakan dalam tehnik pengajarak kosa kata dalam artikel ini. Kuis ini

akan dimodifikasi sedemikian rupa sehingga dapat menjadi salah satu tehnik pengajaran kosa kata yang sangat menantang dan menarik.

Nama Permainan : Guessing Profession.

Tujuan

: Menebak profesi dari mystery guess dengan menggunakan pertanyaan yes, no question.

Jumlah pemain : 4 sampai 12 orang

Scoring

: Score 100 diberikan kepada grup yang bisa menebak profesi dari mystery guess dengan tepat dalam waktu yang telah ditentukan bersama sesuai kesepakatan.

Peralatan

: Karton dipotong berukuran $3 \times 6 \mathrm{~cm}$ dan ditulisi dengan profesi yang akan ditebak. Spidol, Papan tulis, penghapus. Timer (bisa menggunakan jam atau HP).

Persiapan : Siswa yang terdiri dari 4 sampai 12 orang dibagi menjadi dua kelompok dengan kemampuan Bahasa Inggris yang berfariasi. Guru pembimbing dengan menggunakan HP atau jam tangan menentukan durasi lamanya suatu grup diberi kesempatan untuk bertanya tentang profesi dari mystery guest. Mystery guest diambil dari anggota grup yang sedang mendapat giliran bermain. Mystery guest dalam setiap giliran permainan harus selalu bergantian. Setelah penentuan mystery guest kemudian guru pembimbing akan memperlihatkan kartu yang berisi profesi pekerjaan yang harus ditebak oleh anggota grupnya. Kartu profesi tersebut hanya diperlihatkan kepada mystery guess saja kemudian anggota dari grup tersebut akan bertanya hanya dengan menggunakan yes, no question sedangkan mystery guest hanya bisa menjawab "yes" atau "no" atau "can be" 
Prosedur Permainan : Mystery guest duduk menghadap anggota grupnya dan tidak boleh mengatakan apapun selain menjawab pertanyaan anggotanya dengan "yes", "no" atau "can be". Sementara itu grup lawan harus menyimak semua pertanyaan yang diajukan oleh anggota grup yang mendapatkan giliran agar apabila grup yang mendapatkan giliran tidak dapat menebak profesi mystery guest dengan benar maka kartu profesi yang sama akan diberikan kepada grup lawan dengan mystery guess dari grup lawan juga.

Cara menebak : Setiap profesi akan dapat ditelusuri dimana seseorang bekerja, di dalam ruangan atau diluar ruangan, atau suatu profesi bisa ditebak dari alat kerja yang dia gunakan, seragam yang ia kenakan dan dari department dimana dia bekerja dan lain-lain.

Expresi yang sering digunakan:

1. Do you work indoor?

2. Do you work outdoor?

3. Do you have customer?

4. Do you have other person who need your service?
5. Do you receive something form your customer?

6. Does your job need special education such as University?

7. Does your job need specific skill?

8. Does your job need good appearance?

9. Do you receive salary every month?

10. Do wear uniform?

11. Is your uniform blue?

12. Do you work under a department?

13. Do your work under department of Education?

14. Is the department you work close related with money?

15. Do you use tools?

16. Is the tool heavy?

17. Do you work alone?

18. Do you work in a team?

19. Do you work in a shift?

20. Do you work behind the desk? Dan lainlain

Contoh apikasi dalam permainan ini

Misalnya kartu yang ditunjukkan ke mystery guest adalah profesi "Driver" kemudian guru pembimbing menyatakan bahwa katagorinya dalah profesi kemudian urutan pertanyaan yang tepat adalah sebagai berikut:

Panelis: P

Mystery guest:M

P: Do you work indoor?

M: No. (jawaban harus "no" karena seorang supir itu bekerja di luar ruangan.

P: Do you use tool? 
M: Yes (jawaban harus "yes" karena alat tranportasi adalah termasuk alat kerja)

P: Is the tool heavy?

M: Yes (jawaban harus "yes" karena alat yang diapakai bekerja itu berat untuk diangkat)

$\mathrm{P}$ : Is the tool in the form of vehicle?

M: Yes.

P: Do you wear uniform?

M: Can be (jawaban harus "can be" karena sopir ada yang memakai seragam seperti sopir taxi yang bekerja di perusahaan angkutan atau ada juga sopir yang bekerja sendiri sehingga tidak memerlukan seragam dalam bekerja)

Untuk membedakan antara sopir dan pilot harus ditanyakan:

P: Do you work onland?

M: Yes.

P: Do you have customer?

M: Yes.

P: Do you receive salary every month?

M: Can be (Jawaban harus "can be" karena ada sopir yang menerim gaji apabila dia bekerja di perusahaan transportasi namun ada juga yang tidak menerima gaji karena ia bekerja sendiri)

P: Do you deliver something from one place to another?

M: Yes

P: Do you deliver passengers from one place to another?

M: Yes.

P: Do you receive money for customers?

M: Yes.

P: Do you sometime give them change?
M: Yes.

Setelah para panelis yakin betul akan petunjuk profesi yang dipertanyakan maka ketua panelis akan menarik kesimpulan tentang jawaban profesi diikuti dengan berbagai alasan.

P: After we discuss with our partner I gues that he is a "Driver" because he has customers, he delivers someone and some things form one place to another, he receives moneys from them and he also gives them some change.

\section{KESIMPULAN}

Tehnik pengajaran kosa kata dengan menggunakan game atau permainan sangat terasa menyenangkan, disamping mahasiswa dengan mudah akan dapat mengingat kosa kata yang digunakan mereka juga akan bisa menggunakan kosa kata tersebut. Disamping menyenangkan dan mudah diterima oleh mahasiswa, penggunaan game atau permainan mempunyai beberapa kekurangan misalnya kosa kata yang digunakan dalam suatu permainan sangat terbatas sehingga untuk pengajaran kosa kata tidak hanya diperlukan satu tehnik saja tetapi tehnik yang lainnya juga sehingga penguasaak kosa kata akan lebih bervariasi.

\section{REFERENCES}

Ahmadi Mohammad Reza. (2012). Improving Vocabulary Learning in Foreign Language Learning Through Reciprocal Teaching Strategy. Macrothing Institute International Journal of Learning \& Development, Vol 2(No. 6), 186-201.

Alderson, C. (2000). Assessing reading. Cambridge: Cambridge: Cambridge University Press. 
Alqahtami, M. (2015). The Importance of Vocabulary in Language Learning and How to be Taught. International Journal of Teaching and Education, III(3), 21-31.

Anjomshoa Leila and MostafaZamanian. (2014). The Effect of Vocabulary Knowledge on Reading Comprehension of Iranian EFL Learners in Kerman Azad University. International Journal on Studies in English Language and Literature (IJSELL), 2(5), 90-95.

Erlina. (2011). Metodologi Penelitian. Medan: USU Press.

Gu, Y. (2003). Fine brush and freehand: The vocabulary learning art of two successful Chinese EFL learners. TESOL Quarterly, 37, 73-104., 37(73), 104.

Harmer, J. (2001). How to Teach English. London: Longman.

Jeanette S. Decarico. (2001). Teaching English as a Second or Foreign Language (3rd ed.). United States: Heinle \& Heinle Thomson Learning.

Kaivanpanah, S., \&Zandi, H. (2009). The role of depth of vocabulary knowledge in reading comprehension in EFL context. Journal of Applied Sciences, 9(4), 698-706.

Laufer B. (2003). Vocabulary acquisition in a second language: Do learners really acquire more vocabulary by reading? Some empirical evidence. Applied Linguistics, 19, 255-271.

Lervåg, A., \& Aukrust, V. G. (2010). Vocabulary knowledge is a critical determinant of the difference in reading comprehension growth between first and second language learners. Journal of Child Psychology and Psychiatry, 51(5), 612-
620, 51(5), 612-616.

Nation, I. S. P. (2011). Learning vocabulary in another language. Cambridge: Cambridge University Press.

Palincsar, A. S., \& Brown, A. L. (1985). Activities to promote "reading with your mind. New York.

Qian, D. (2002). Investigating the relationship between vocabulary knowledge and academic reading Performance (No. 52).

Read. J. (2000). Assessing vocabulary. Cambridge: Cambridge University Press.

Schmitt N. (1999). The relation between TOEFL vocabulary items and meaning, association, 325 collocation, and wordclass knowledge (No. 16).

Schmitt N. (2000). Vocabulary in language teaching. Cambridge: Cambridge: Cambridge University Press.

Stuart Webb. (2015). words to express their thoughts to others. International Journal of Teaching and Educatiion, III(3).

Thorburry S. (2002). How to teach vocabulary. England: Pearson Education Limited.

Tompkins, G. E. (2011). Literacy in the early grades: A successful start for prek-4 readers. Boston: Pearson.

Ur, P. (1998). A course in language teachin. Cabridge: Cabridge University Press.

Walter, \& J. (2004). "Teaching the use of context to infer meaning: A longitudinal survey of L1 and L2 vocabulary research." Language Teaching, 37(4), 243-252.

Zhang, L. J., \& Anual, S. B. (2008). The role of vocabulary in reading comprehension: The case of secondary school students learning English in Singapore. RELC Journal, 39(1), 51-76. 